\title{
Articles
}

\section{The Regulation of Screening of Foreign Direct Investments in the European Union}

\author{
A közvetlen külföldi befektetések átvilágításának szabályozása \\ az Európai Unióban
}

\begin{abstract}
This paper examines the framework and cooperation mechanisms set up by Regulation (EU) 2019/452 of the European Parliament and of the Council of 19 March 2019 establishing a framework for the screening of foreign direct investments into the Union. The Regulation merely gives a framework for the coordination of national legislation, and member states can still decide if they want to set up screening mechanisms and to screen foreign direct investments. The pandemic has accelerated these processes, and more and more European Union member states enacted legislation relating to the screening of foreign direct investments in strategic branches of the economy. The Commission has also issued a Guidance at the end of March 2020, in which it warns about the risk that the Coronavirus related economic shock might have on strategic industries, especially on healthcare related industries. At the same time, recognizing the importance of foreign direct investments for the economy, it pointed out in the Guidance the necessity to find a balance between the need for foreign capital and the protection of European Union strategic industries using appropriate screening tools.
\end{abstract}

Keywords: European Union, foreign direct investment, screening, Regulation (EU) 2019/452

\section{ABSZTRAKT}

A tanulmány az Európai Unióba irányuló közvetlen külföldi befektetések átvilágitási keretének létrehozásáról szóló 2019. március 19-i (EU) 2019/452 európai parlamenti és tanácsi rendelet által létrehozott keretet és együttmüködési mechanizmust vizsgálja. A Rendelet csak keretrendszert határoz meg a nemzeti szabályozás koordinálása céljából, a tagállamok szabadon eldönthetik, hogy fel kivánnak-e állitani a közvetlen külföldi befektetések kapcsán átvilágitási mechanizmusokat. A pandémia azonban felgyorsitotta ezeket a folyamatokat, és egyre több Európai Uniós tagország hozott a külföldi közvetlen befektetések átvilágitásával kapcsolatos jogszabályokat stratégiai jelentőségü gazdasági szektorokban. A Bizottság szintén kiadott egy Bizottsági Iránymutatást 2020 március végén, amelyben felhívja a figyelmet a koronavírussal kapcsolatos gazdasági sokk

* Zoltán Vig, PhD, Senior Lecturer, University of Szeged (Hungary), Faculty of Law; e-mail: jogasz@gmail.com. 
hatására a stratégiai ágazatokban, föleg az egészségügyi ellátással kapcsolatos ágazatokban. Ugyanakkor, felismerve a közvetlen külföldi befektetések jelentőségét a gazdaság számára, kiemeli az Iránymutatásban, hogy meg kell találni az egyensúlyt a külföldi tőke szükségessége és az Európai Uniós stratégiai iparágak védelme között a megfelelő átvilágítási eszközök felhasználásával.

Kulcsszavak: Európai Unió, közvetlen külföldi befektetés, átvilágitás, 2019/452 EU rendelet

The days of a unipolar global system that emerged during the end of the $20^{\text {th }}$ Century are slowly coming to an end. Since the beginning of the $21^{\text {st }}$ Century, the economic and political dominance of the United States has been fading. The 2008 World Economic Crisis greatly accelerated this process. With the weakening of the United States we have been facing a process of global isolation and protectionism. The same can be observed in relation to the World Trade Organization negotiations. Protectionism is spreading, ${ }^{1}$ and not only with regards to international trade, but also the freedom of international investments is becoming more and more restricted.

The European Union also reacted to this tendency last year, and with a bit of irony we might say that it is never too late, and thus it passed Regulation (EU) 2019/452 of the European Parliament and of the Council of 19 March 2019, establishing a framework for the screening of foreign direct investments into the Union (hereinafter: Regulation). ${ }^{2}$ The Regulation is applicable from October $11,2020 .{ }^{3}$ The pandemic has accelerated these processes, and more and more European Union member states have enacted legislation related to the screening of foreign investments in strategic branches of the economy. The Commission issued a Guidance at end of March 2020, in which it warns about the risk that the coronavirus related economic shock might have on strategic industries, especially on healthcare related industries. At the same time, recognizing the importance of foreign direct investments for the economy, it points out in the Guidance the necessity to find a balance between the need for foreign capital and the protection of European Union strategic industries. ${ }^{4}$

1 See Csongor István Nagy, 'World Trade, Imperial Fantasies and Protectionism: Can You Really Have Your Cake and Eat It Too?' (2019) 26(1) Indiana Journal of Global Legal Studies 87-132. <https://ssrn.com/abstract=3363951> accessed 28 July 2020 (doi.org/10.2979/indjglolegstu.26.1.0087).

2 OJ L 079I 21.3.2019, p. 1. The Regulation has been amended by the Commission Delegated Regulation (EU) 2020/1298 of 13 July 2020 amending the Annex to Regulation (EU) 2019/452 of the European Parliament and of the Council establishing a framework for the screening of foreign direct investments into the Union (OJ L 304, 18.9.2020, p. 1-3). The consolidate version of the Regulation can be found at the following link: <https://eur-lex. europa.eu/legal-content/EN/TXT/?uri=CELEX\%3A02019R0452-20200919> accessed 20 May 2021. There are several works on the issue of screening of foreign direct investments in the EU, see e.g.: Cees Verburg, 'The Screening of Foreign Direct Investments into the European Union: Regulation 2019/452 and Its Implications for Energy Investments' (2019) 13 European Energy Law Report 219-244; Giani Pandey, Davide Rovetta, Agnieszka Smiatacz, 'How Many Barriers Should a Steeple Chase Have: Will the EU's Proposed Regulation on Screening of Foreign Direct Investments Add yet More Delaying Barriers When Getting a Merger Deal through the Clearance Gate, and Other Considerations' (2019) 14(2) Global Trade and Customs Journal 56-65.

${ }^{3}$ Regulation, Art 17.

${ }^{4}$ Article 63(1) of the Consolidated version of the Treaty on the Functioning of the European Union (Official Journal C 326, 26/10/2012 P. 0001 - 0390) provides as a general rule that: "all restrictions on the movement of capital between Member States and between Member States and third countries shall be prohibited." 
For this, appropriate screening tools are needed according to the Commission. Therefore, it encourages member states which have a screening mechanism to use it, and those without it to introduce one. ${ }^{5}$

The examination of the Regulation in Europe is timely for several reasons. There is obviously a realignment on the international economic scene, and several researchers forecast the twilight of liberal capitalism. ${ }^{6}$ Countries are becoming more restrictive in this area and trying to protect crucial sectors in their economies. At the same time, national economies worldwide still need foreign working capital, and it is still crucial for every modern economy, especially in hard times. The European Union tried to be open in this regard, but it seems that there is no reciprocity among large players. ${ }^{7}$ Reforms in China have slowed down, while it seems that the United States is moving towards protectionism. ${ }^{8}$ It also seems that there will be strong economic and military competition between China and the United States in the future, at the same time, the world economy will remain highly interdependent.

\section{Providing a framework for screening}

The Regulation, as its full title states, merely provides a framework for the coordination of national legislation, and member states still have the responsibility to set up screening mechanisms and to screen foreign direct investments. At the same time, in the European Union, being a single market, coordination of policies related

${ }^{5}$ Guidance to the Member States concerning foreign direct investment and free movement of capital from third countries, and the protection of Europe's strategic assets, ahead of the application of Regulation (EU) 2019/452 (FDI Screening Regulation) <https://trade.ec.europa.eu/doclib/docs/2020/march/tradoc_158676. pdf> accessed 24 July 2020.

${ }^{6}$ Joseph Stiglitz, 'Neoliberalism must be pronounced dead and buried. Where next?' The Guardian (30 May 2019) <https://www.theguardian.com/business/2019/may/30/neoliberalism-must-be-pronouced-dead-andburied-where-next> accessed 26 November 2020; Joseph Stiglitz, People, Power, and Profits: Progressive Capitalism for an Age of Discontent (W. W. Norton and Company 2019) 8; John J. Mearsheimer, 'Bound to Fail: The Rise and Fall of the Liberal International Order' (2019) 43(4) International Security <https://doi. org/10.1162/isec_a_00342> accessed 14 July 2020.

${ }^{7}$ European Commission, 'Reflection Paper on Harnessing Globalisation' 15 <https://ec.europa.eu/commission/sites/beta-political/files/reflection-paper-globalisation_en.pdf> accessed 22 July 2020.

8 This process has already started after the economic crisis of 2008, intensified during Trump's presidency, and until now there is no substantial change (only general promises) in President Biden's attitude towards issues like the WTO DSB blockage, the Trans-Pacific Agreement (TPP), the Transatlantic Trade and Investment Partnership (TTIP), or towards the improvement of economic relationship with China. See e.g. 'US and China trade angry words at high-level Alaska talks' BBC (19 March 2021) <https://www.bbc.com/ news/world-us-canada-56452471> accessed 17 May 2021; 'US and China publicly rebuke each other in first major talks of Biden era' The Guardian (19 March 2021) <https://www.theguardian.com/world/2021/mar/19/ us-china-talks-alaska-biden-blinken-sullivan-wang> accessed 17 May 2021; See also: Soli Özel 'US Isolationism: How to Step Back Without Stepping Away? Interview with Charles Kupchan' Institut Montaigne (12 January 2021) <https://www.institutmontaigne.org/en/blog/us-isolationism-how-step-back-without-steppingaway> accessed 17 May 2021. In addition, the robust US screening mechanism is also a good example for moving towards a more closed economy. See Jason Jacobs, 'Tiptoeing the Line Between National Security and Protectionism: A Comparative Approach to Foreign Direct Investment Screening in the United States and European Union' (2019) 47(2) International Journal of Legal Information 105-117. 
to the regulation of foreign direct investments is definitely needed. As in many other cases, the recital of the Regulation contains lot of useful information, and we can learn the reasons for the adoption of the legal act, the purpose of the act and so on. ${ }^{9}$ First of all, the recital explains the legal bases for the enactment of the Regulation, referring to article 3(1) of the Treaty on the Functioning of the European Union, which states that "The Union shall have exclusive competence in the following areas: ... (e) common commercial policy", and foreign direct investment falls within this field. ${ }^{10}$ Furthermore, article 3(5) of Treaty on European Union states that "In its relations with the wider world, the Union shall ... contribute to the protection of its citizens." "11 This is legitimate even under international treaties like the agreement establishing the World Trade Organisation or the Organisation for Economic Co-operation and Development, because it is done on the grounds of security or public order. ${ }^{12}$ At the same time, as such foreign direct investments might affect national security (this is actually, the reason for regulating this field), and article 4 (2) of the Treaty on European Union states that "national security remains the sole responsibility of each Member State", the recital emphasizes that the Regulation is only a common framework coordinating this issue, and member states can decide if they want to set up a screening mechanism at all. ${ }^{13}$ Currently, 18 member states have legislation related to screening of foreign direct investments:

${ }^{9}$ Thomson Reuters Practical Law Glossary <https://uk.practicallaw.thomsonreuters.com/w-009-6368?transiti onType=Default\&contextData=(sc.Default)\&firstPage=true\&bhcp $=1>$ accessed 22 July 2020. Some authors claim that the purpose of recitals is to set out concise reasons for the chief provisions of the enacting terms. However, recitals have no legal value, and they cannot be relied on as a ground for derogating from the actual provisions of the act in question. Recitals have no independent operative effect under EU law. At the same time, recitals are often used in interpretation by the courts, and operative provision are often interpreted in light of the recital. Tadas Klimas, Jflrate Vaitiukait, 'The Law of Recitals in European Community Legislation' (2008) 15(1) ILSA Journal of International \& Comparative Law 67, 76, 85 <https://nsuworks.nova.edu/cgi/ viewcontent.cgi?article=1643\&context=ilsajournal> accessed 23 July 2020 .

${ }^{10}$ Recital 6. See also article 207 (1) of the Consolidated version of the Treaty on the Functioning of the European Union (Official Journal C 326, 26/10/2012 P. 0001 - 0390), which provides that: "The common commercial policy shall be based on uniform principles, particularly with regard to ... foreign direct investment..."

${ }^{11}$ Regulation, rec. 2.

${ }^{12}$ Regulation, rec. 3. Csongor István Nagy, 'Free Trade, Public Interest and Reality: New Generation Free Trade Agreements and National Regulatory Sovereignty' (2018) 9 Czech Yearbook of International Law 199$203<$ <ttps://ssrn.com/abstract=3172064> accessed 28 July 2020; Csongor István Nagy, 'Clash of Trade and National Public Interest in WTO Law: The Illusion of 'Weighing and Balancing' and the Theory of Reservation' (2020) 23(1) Journal of International Economic Law 143-163 <https://ssrn.com/abstract=3572398> accessed 28 July 2020 (doi: 10.1093/jiel/jgz028).

${ }^{13}$ Regulation, rec. 8. 
Table 1. Legislation relating to screening of foreign direct investments in member states ${ }^{14}$

\begin{tabular}{|c|c|}
\hline Member state & Legal act \\
\hline Austria & $\begin{array}{l}\text { Foreign Commerce Act of } 2011 \text { (Section 25a) } \\
\text { Austrian Investment Control Act / ICA, in force since } 25 \text { July } 2020 \text { except for } \\
\text { those provisions destined to enter into force by } 11 \text { October } 2020\end{array}$ \\
\hline Czech Republic & Act No. 34/2021 on screening of foreign direct investments \\
\hline Denmark & $\begin{array}{l}\text { Act on War Material (The Danish Consolidated Act No. } 1004 \text { of October } 22 \\
\text { 2012) } \\
\text { Act on the continental shelf and certain pipelines installations on territorial } \\
\text { waters (The Danish Consolidated Act No. } 1189 \text { of September } 21 \text { 2018) }\end{array}$ \\
\hline Germany & $\begin{array}{l}\text { Foreign Trade and Payments Act [of } 6 \text { June } 2013 \text { (Federal Law Gazette I p. } \\
\text { 1482), as last amended on } 18 \text { June 2020] } \\
\text { Article 4, 5, } 13 \text { and } 15 \\
\text { Foreign Trade and Payments Ordinance [of } 2 \text { August } 2013 \text { (Federal Law } \\
\text { Gazette [BGBI.] Part I p. 2865), as last amended on n } 29 \text { October 2020] } \\
\text { Article } 55 \text { to } 62\end{array}$ \\
\hline Finland & $\begin{array}{l}\text { Act on the Screening of Foreign Corporate Acquisitions (172/2012) } \\
\text { Act on transfers of real estate property requiring special permission (470/2019) } \\
\text { Act on the Screening of Foreign Corporate Acquisitions (172/2020, amend- } \\
\text { ments } 2.10 .2020 / 682)\end{array}$ \\
\hline France & $\begin{array}{l}\text { Financial and monetary code, Legal section, Book I, Title V : Financial deal- } \\
\text { ings with foreign countries, Articles L.151-1 to L.151-7 } \\
\text { Financial and monetary code, Infra-legal section, Book I, Title V : Financial } \\
\text { dealings with foreign countries, Chapter I : Investments subject to authoriza- } \\
\text { tion, Articles R.151-1 to R.151-18 } \\
\text { Order of } 31 \text { December } 2019 \text { relating to foreign investments in France } \\
\text { French Commercial Code, Article L.233-3, Article L.430-1, Article } 459 \text { of the } \\
\text { Customs code (penal sanctions) }\end{array}$ \\
\hline Hungary & $\begin{array}{l}\text { Act LVII of } 2018 \text { on Controlling Foreign Investments Violating Hungary's } \\
\text { Security Interests }{ }^{15} \\
\text { Government Decree 246/2018. (XII. 17.) on the Implementation of Act LVII } \\
\text { of } 2018 \text { on Controlling Foreign Investments Violating Hungary's Security } \\
\text { Interests } \\
\text { Act No. LVIII of } 2020 \text { on the Transitional Rules related to the End of the State } \\
\text { of Danger and Pandemic Preparedness (section } 85 \text {. Paragraphs } 276-292 \text { ) } \\
\text { Government Decree } 289 / 2020 \text { (VI. 17.) defining the measures required for } \\
\text { the economic protection of companies having their seats in Hungary }\end{array}$ \\
\hline
\end{tabular}

${ }^{14}$ Source: List of screening mechanisms notified by Member States (28 July 2020) <https://trade.ec.europa.eu/ doclib/docs/2019/june/tradoc_157946.pdf> accessed 17 May 2021.

15 On the analyses of the law see: Szilárd Gáspár Szilágyi, 'Country Report on Hungary and Romania' in Hindelang and Moberg (eds.), A Common European Law on Investment Screening (Springer 2020) <https://ssrn. com/abstract=3527586> accessed 3 August 2020 (doi: 10.1007/16495_2020_25). 


\begin{tabular}{|c|c|}
\hline Member state & Legal act \\
\hline Italy & 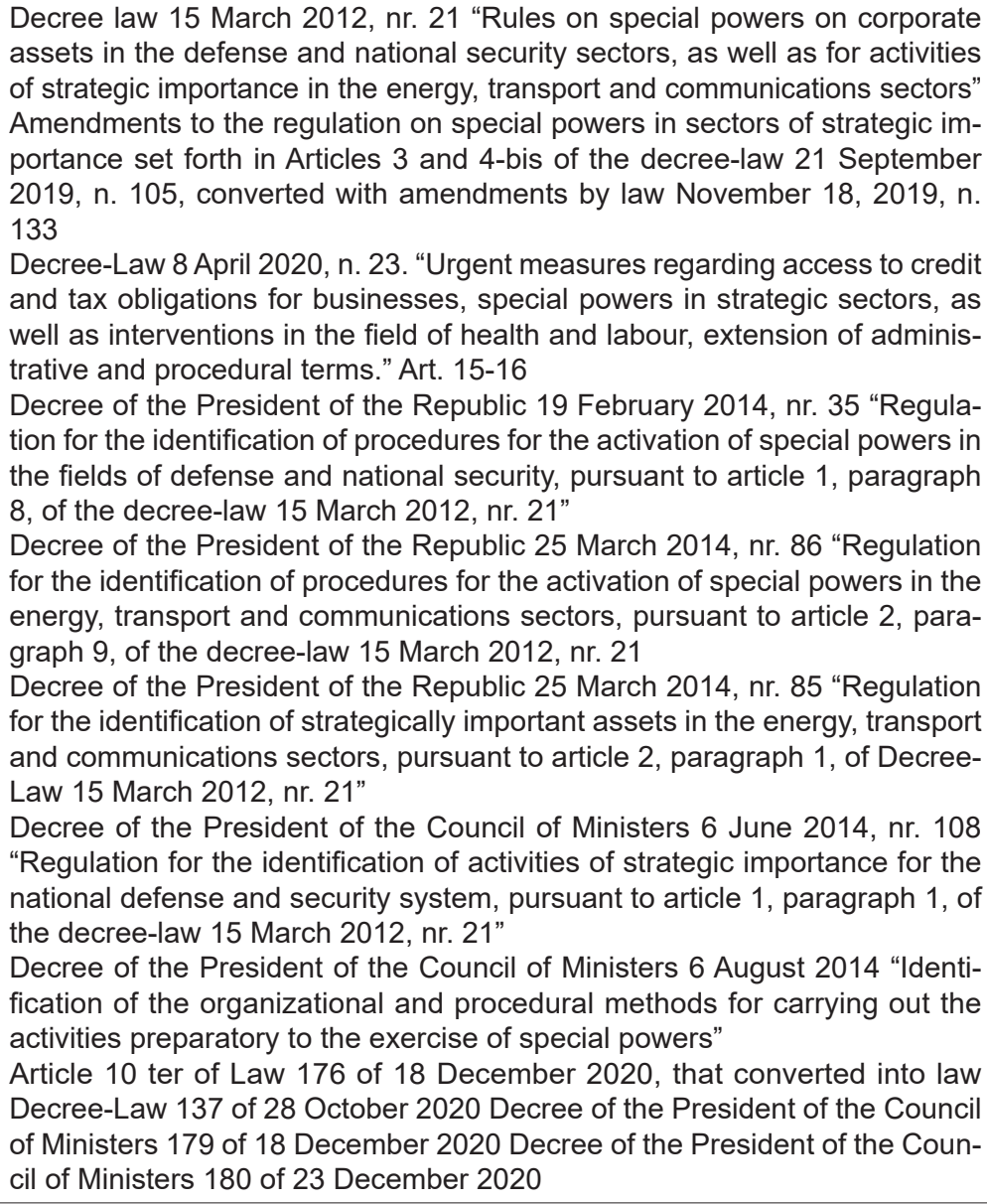 \\
\hline Latvia & $\begin{array}{l}\text { National Security Law, Chapter VI-Restrictions on Commercial Companies } \\
\text { of Significance to National Security } \\
\text { Regulation No. } 606 \text { adopted on } 3 \text { October } 2017 \text { regarding the Information to } \\
\text { be Submitted to the Authority Determined in the National Security Law and } \\
\text { the Handling of Information on Foreign Direct Investments (6 October 2020) } \\
\text { Regulations of the Cabinet of Ministers of October 3, } 2017 \text { No. } 606 \text { "Regula- } \\
\text { tions regarding the information to be submitted to the institution specified in } \\
\text { the National Security Law and activities with information regarding foreign } \\
\text { direct investment }\end{array}$ \\
\hline
\end{tabular}




\begin{tabular}{|c|c|}
\hline Member state & Legal act \\
\hline Lithuania & $\begin{array}{l}\text { The Law on Protection of Objects Important to Ensuring National Security } \\
\text { of the Republic of Lithuania, No. IX-1132 (new edition No. XIII992 dated } \\
2018-01-12 \text { ) } \\
\text { Resolution on the Rules of Procedure of the Commission approved by the } \\
\text { Government, No. } 1540 \text { (new edition No. } 266 \text { dated } 21-03-2018 \text { ) } \\
\text { Resolution on the Determination of the Protection Zones of Importance to } \\
\text { National Security approved by the Government, No. } 1252 \text { (new edition No. } \\
746 \text { dated 25-07-2018) The Law on the Protection of Objects of Importance } \\
\text { to Ensuring National Security, No. XIII-3257 } \\
\text { Resolution of the Government No 1072, concerning the appointment of the } \\
\text { Ministry of Foreign Affairs of the Republic of Lithuania to perform functions } \\
\text { Resolution on the Rules of Procedure of the Commission for Coordination of } \\
\text { Protection of Objects of Importance to Ensuring National Security approved } \\
\text { by the Government, No. } 1540 \text { (new edition No. } 1213 \text { Valid from Nov 4, 2020) }\end{array}$ \\
\hline Malta & ACT No. LX of 2020 of 18 December 202011 \\
\hline The Netherlands & $\begin{array}{l}\text { Electricity Act } 1998 \text { (Article } 86 \mathrm{f} \text { ) } \\
\text { Ministerial Regulation regarding the notification of change of control Elec- } \\
\text { tricity Act } 1998 \text { and Gas Act } \\
\text { Gas Act (Article } 66 \mathrm{e} \text { ) } \\
\text { Ministerial Regulation regarding the notification of change of control Elec- } \\
\text { tricity Act } 1998 \text { and Gas Act } \\
\text { Telecommunications Act (Chapter 14a) } \\
\text { Ministerial Decree regarding unwanted control telecommunication }\end{array}$ \\
\hline Poland & $\begin{array}{l}\text { Act of July } 24,2015 \text { on the control of certain investments } \\
\text { Act of } 19 \text { June } 2020 \text { on Subsidies on Interest on Bank Loans Granted to } \\
\text { Entrepreneurs Affected by COVID-19 and on the Simplified Procedure for } \\
\text { the Approval of Arrangements in Connection with COVID-19 }\end{array}$ \\
\hline Portugal & $\begin{array}{l}\text { Decree-Law } n^{\circ} .138 / 2014 \text {, of } 15 \text { September, published in the DR } n^{\circ} 177 \text {, } \\
\text { series I, from } 15.09 .2014\end{array}$ \\
\hline Romania & $\begin{array}{l}\text { Law of competition } 21 \text { of April 10th } 1996 \text { Republished and amended } \\
\text { Art. } 47 \text { (9)-(12) }\end{array}$ \\
\hline Slovak Republic & Act No. 45/2011 Coll. on Critical Infrastructure as amended \\
\hline Slovenia & $\begin{array}{l}\text { Act Determining the Intervention Measures to Mitigate and Remedy the } \\
\text { Consequences of the Covid-19 Epidemic }\end{array}$ \\
\hline
\end{tabular}




\begin{tabular}{|c|c|}
\hline Member state & Legal act \\
\hline Spain & $\begin{array}{l}\text { Royal Decree } 137 / 1993 \text {, which approves the regulation on weapons. } \\
\text { Royal Decree } 664 / 99 \text {, on foreign investment Law } 19 / 2003 \text {, on the legal sys- } \\
\text { tem on transfers of capitals and foreign economic transactions and specific } \\
\text { measures for the prevention of money laundering } \\
\text { Royal Decree-Law } 8 / 2020 \text {, on urgent extraordinary measures to address } \\
\text { the economic and social impact of COVID-19, Final disposition } 4 \\
\text { Royal Decree-Law } 11 / 2020 \text {, of March } 31 \text {, adopting urgent additional mea- } \\
\text { sures in the social and economic sphere to confront COVID19, Transitional } \\
\text { disposition } 2 \text {, Final disposition } 3 \\
\text { Law } 7 / 2010 \text {, General Law on audiovisual Communication } \\
\text { Royal Decree-Law } 34 / 2020 \text {, of } 17 \text { November, urgent measures to support } \\
\text { business solvency and the energy sector, and in the field of taxation. (see } \\
\text { Single Transitory Provision and Fourth Final Provision) } \\
\text { Single Transitory Provision - temporary regime for the suspension of the } \\
\text { liberalisation of certain foreign direct investments made by residents of EU } \\
\text { and EFTA countries } \\
\text { Fourth Final Provision - modifies the article } 7 \text { bis of the Law } 19 / 2003 \text {, of } \\
\text { July } 4 \text {, on legal regime of movements of capital and economic transactions } \\
\text { abroad and on certain measures for prevention of money laundering } \\
\text { Law } 3 / 2013 \text {, creating the National Commission on Markets and Competition } \\
\text { Law } 9 / 2014 \text { on Telecommunications }\end{array}$ \\
\hline
\end{tabular}

We can see that several member states, already before the enactment of the Regulation, had legislation related to the screening of foreign investments, meaning that to a certain extent these countries considered some foreign direct investments as threat to their national security.

Operative provisions of the Regulation emphasize that it only provides a framework, and member states can individually decide on the need for screening foreign investments. ${ }^{16}$

The Regulation also defines several terms, including foreign direct investment ${ }^{17}$, foreign investor ${ }^{18}$ and screening ${ }^{19}$. These definitions are clear; however, two things might be pointed out. Firstly, that the Regulation does not cover portfolio investments. This can be underpinned also by the Opinion of the European Court of Justice, which states that "The use, by the framers of the FEU Treaty, of the words 'foreign direct investment' in Article 207(1) TFEU is an unequivocal expression of their intention not to include other foreign investment in the common commercial policy. Accordingly, commitments vis-à-vis a third State relating to other foreign investment do not fall

\footnotetext{
${ }^{16}$ Regulation, Art. 1.

17 Investment "means an investment of any kind by a foreign investor aiming to establish or to maintain lasting and direct links between the foreign investor and the entrepreneur to whom or the undertaking to which the capital is made available in order to carry on an economic activity in a Member State, including investments which enable effective participation in the management or control of a company carrying out an economic activity."

${ }^{18}$ Foreign investor "means a natural person of a third country or an undertaking of a third country, intending to make or having made a foreign direct investment."

$16{ }^{19}$ Screening "means a procedure allowing to assess, investigate, authorise, condition, prohibit or unwind foreign direct investments."
} 
within the exclusive competence of the European Union pursuant to Article 3(1)(e) TFEU." 20 Secondly, that foreign investors are investors from third, non-European Union countries. ${ }^{21}$ However, the most "problematic" issues, such as "security" and "public order" are not defined, it being left to the member states and their legal systems to define these terms. ${ }^{22}$ This might result in significant differences, as "security" is usually a political issue. ${ }^{23}$ The new (provisional/transitional because of the pandemic) Hungarian law on screening (Act No. LVIII of 2020) for example introduces the term "state interest" and defines it as public interest related to the security and operability of networks and equipment, and to the continuity of supply, not regulated by sectoral European Union and national law. ${ }^{24}$

Generally, member states are free to set up their screening mechanisms, however, there are some basic principles (or safeguards for foreign investors), enumerated in Article 3 that should be respected. For example, rules and procedures should be transparent, and they should not discriminate between third countries. Timeframes and specific circumstances triggering screening, grounds for screening and detailed procedural rules should also be specified in national screening regulations. ${ }^{25}$

In addition, the Regulation emphasizes the importance of protecting confidential information obtained by the member state carrying out the screening. ${ }^{26}$ Data protection is also mentioned in Article 10, which places a similar obligation on the Commission, and in Article 14, which deals with processing of personal data obtained in relation to investment screening.

The Regulation provides that screening mechanisms should be such as to allow member states to take into account the comments of other member states and the opinion of the Commission. However, as we are going to see, examining the three mechanisms set up by the Regulation, member states should only "give due consideration to the comments and opinions." Only under the third mechanism, when

${ }^{20}$ Opinion 2/15 of the Court (Full Court) 16 May 2017 <https://eur-lex.europa.eu/legal-content/EN/TXT/?uri=C ELEX\%3A62015CV0002\%2801\%29> accessed 3 August 2020.

${ }^{21}$ Carlos Esplugues, 'Towards a Common Screening System of Foreign Direct Investment on National Interest Grounds in the European Union' (2018) 11(2) Culture, Media and Entertainment Law 4 (doi: 10.20995/ cmel.12.1.1).

22 "Member States are still, in principle, free to determine the requirements of public policy and public security in the light of their national needs, those grounds must, in the Community context and, in particular, as derogations from the fundamental principle of free movement of capital, be interpreted strictly, so that their scope cannot be determined unilaterally by each Member State without any control by the Community institutions" (ECJ C-54/99, para. 17 <http://curia.europa.eu/juris/showPdf.jsf;jsessionid=3E13A6FF08D23C547 CA3469305560 61 ?text $=\&$ docid $=45038 \&$ pagelndex $=0 \&$ doclang $=E N \&$ mode $=I s t \& d i r=\& o c c=$ first\&part $=1 \& \mathrm{c}$ id $=14074965>$ accessed 8 August 2020). Esplugues concludes based on the case law of the European Court of Justice, that public policy and public security may be relied on, only if there is a genuine and sufficiently serious threat to a fundamental interest of society. Moreover, those derogations must not be misapplied so as, in fact, to serve purely economic ends. Ibid. 14.

${ }^{23}$ Zwartkruis and de Jong agrees that it is difficult to define security. See Zwartkruis, Wolf and de Jong, Bas J., 'The EU Regulation on Screening of Foreign Direct Investment: A Game Changer?' (2019) European Business Law Review 3 <https://ssrn.com/abstract=3428247> accessed 28 July 2020.

${ }^{24}$ Law no. LVIII of 2020, sec. 276 (1).

${ }^{25}$ Regulation, Art. 3 (2).

${ }^{26}$ Regulation, Art. 3 (4). 
the foreign investment is likely to affect projects or programs of Union interest, ${ }^{27}$ the member state (target of the investment) is obliged to give explanation to the Commission if it does not follow its opinion. ${ }^{28}$

An important procedural principle laid down by the Regulation is that member states should ensure the possibility of recourse against screening decisions. ${ }^{29}$ For example, in Hungary prohibiting decisions can be challenged in front of the Budapest High Court in a non-contentious proceeding..$^{30}$ However, viewed from practical aspect, if screening decisions are subject to court review, the whole procedure may take long time, and it is not efficient for the investor.

There is also a provision that obliges member states to maintain the laws related to screening thus preventing circumvention of the screening mechanisms and screening decisions. ${ }^{31}$

\section{Factors that should be taken into consideration}

Article 4 enumerates factors that should be taken into consideration when examining a foreign direct investment's effect on security or public order by member states or the Commission. So, it should not be forgotten that the ground for screening is the effect of the investment on the security or public policy of the member state, and cannot be for example the investment's effect on its economy. ${ }^{32}$ There are two groups of factors. The first contains the list of so-called sensitive sectors. There are five categories, however, though this is not a closed list, and member states may expand it. First of all, these are critical infrastructures (like energy, transport, water, health, communications, media, data processing or storage, aerospace, defence, electoral or financial infrastructure) and sensitive facilities, as well as land and real estate crucial for the use of such infrastructure. A good example of critical transport infrastructure being invested into by a foreign power is the case of the Piraeus Port or Harbor in Greece, the majority of which was bought up by one of China's premier shipping firms, Cosco, in 2016, followed by a 660 million USD investment in 2019. The Piraeus Harbor is a major hub of sea-based transportation and general shipping. ${ }^{33}$

The next category covers critical technologies and dual use items (artificial intelligence, robotics, semiconductors, cybersecurity, aerospace, defence, energy stor-

${ }^{27}$ For the broad concept of 'Union interest', see Balázs Horváthy, 'The concept of 'Union interest' in EU external trade law' (2014) 55(3) Acta Juridica Hungarica 261-276. <https://papers.ssrn.com/sol3/papers. cfm?abstract_id=2587705> accessed 28 July 2020 (doi: 10.2139/ssrn.2587705).

${ }^{28}$ See infra Part 3.

${ }^{29}$ Regulation, Art. 3 (5).

${ }^{30}$ Act No. LVIII of 2020, sec. 285 (1).

${ }^{31}$ Regulation, Art. 3 (6).

32 Zwartkruis and de Jong (n 23) 16; Esplugues (n 21).

${ }^{33}$ Silvia Amaro, 'China bought most of Greece's main port and now it wants to make it the biggest in Europe' CNBC (15 November 2019) <https://www.cnbc.com/2019/11/15/china-wants-to-turn-greece-piraeus-portinto-europe-biggest.html> accessed 5 August 2020. 
age, quantum and nuclear technologies, nanotechnologies and biotechnologies). These are primarily important to keep the European Union economy competitive in the global market. A well-known example in this field involves China once again: in 2016, one of the largest German robotics companies, KUKA, was subjected to a hostile takeover by a Chinese appliance making company called Midea. It should be noted that at the time, the German government approved of the transaction. ${ }^{34}$ Since then, despite general guarantees about maintaining staff numbers and German operations, the now-Chinese controlled KUKA experienced significant downturns in share price, a reduction in revenue forecasts, and faces an uncertain future. ${ }^{35}$

Other sensitive sectors are the supply of critical inputs (among others, energy, raw materials, food). A French example of this is that the China Investment Corporation $(\mathrm{CIC})$ acquired a $30 \%$ stake in $\mathrm{ENGIE},{ }^{36}$ a company that serves as a primary player in the supply of thermal, renewable and other energy within Europe (and also plays a crucial role in infrastructure, especially in the field of natural gas, where it is claimed to be the number one company participating in its transport and storage). ${ }^{37}$ In a similar fashion, the UK actually delayed the building of a nuclear power plant because of security concerns over a $30 \%$ Chinese stake in the project. ${ }^{38}$

The fourth is access to sensitive information (like personal data, etc.). Though, member states have not yet formally instigated proceedings against the application at the time of writing and it is only an 'indirect' example, the popular social media application known as TikTok came under fire recently for allegedly being a tool of Chinese governmental spying, essentially alleged to be a tool for China to harvest personal data on a global scale, through the murky relationship between TikTok's parent company and the Chinese government, as well as a recent Chinese Law that mandated corporate cooperation in intelligence operations. Already, Japan and the United States have taken steps against the application, and a European reaction also seems highly probable. ${ }^{39}$

And finally, freedom and pluralism of the media. ${ }^{40}$ These are important to ensure the stability of supply of the industry, and also for political stability of the member

34 'Berlin approves Kuka sale to Midea' (DW, 17 August 2016) <https://www.dw.com/en/berlin-approves-kukasale-to-midea/a-19479483> accessed 5 August 2020.

${ }^{35}$ Nik Martin, 'German robot maker Kuka's CEO to be replaced by Chinese owners' DW (24 November 2018) <https://www.dw.com/en/german-robot-maker-kukas-ceo-to-be-replaced-by-chinese-owners/a-46440242> accessed 5 August 2020

36 'ENGIE and China Investment Corporation (CIC) signed MOU' ENGIE (30 June 2015) <https://www.engie. com/en/journalists/press-releases/engie-china-investment-corporation-signed-mou> accessed 5 August 2020.

37 'Thermal electricity' (ENGIE) <https://www.engie.com/en/activities/thermal-energy/thermal-power-stations> accessed 5 August 2020; 'Transportation' (ENGIE) <https://www.engie.com/en/activities/infrastructures/transportation> accessed 5 August 2020.

38 'Hinkley Point C to Go Ahead After EDF Board Approves Project' (The Guardian, 28 July 2016) <https://www. theguardian.com/business/2016/jul/28/hinkley-point-c-to-go-ahead-after-edf-board-approves-project, https:// www.china-briefing.com/news/chinese-fdi-eu-top-4-economies> accessed 5 August 2020.

${ }^{39}$ Rebecca Jennings, 'What's going on with TikTok, China, and the US government?' Vox (16 December 2019) <https://www.vox.com/open-sourced/2019/12/16/21013048/tiktok-china-national-security-investigation> accessed 5 August 2020.

${ }^{40}$ Regulation, Art. 4 (1). 
states. A good example of this was when in 2015 the Chinese energy company CEFC invested into the Czech media company, Empresa Media, which controlled a number of publications. Most concerningly, according to the allegations, these publications all switched to a strongly pro-China narrative since this investment. ${ }^{41}$

As already mentioned, the above list is not closed. Thus, for example the new (provisional/transitional) Hungarian law on screening (Act No. LVIII of 2020) and its executive Decree ${ }^{42}$ in its annex adds several new sectors to those enumerated in Act LVII of 2018 on Controlling Foreign Investments Violating Hungary's Security Interests, which include, among others, retail trade and quartering and catering in tourism. It is doubtful whether investment into these sectors can seriously affect public security or public order of a country. In addition, if too many sectors are covered by screening, investors might lose interest in investing in the given economy.

The second group contains those factors which should be taken into consideration when it comes to the assessment of the foreign investor. First of all, it should be taken into consideration whether the foreign investor is controlled (or funded) by a government. The relevance of this factor was increased following the 2008 global economic crisis, after which China has intensified its investments globally, which also raised awareness of the matter in Brussels. In particular, China has become very interested in investing in European infrastructure companies, obtaining various degrees of control over vital installations such as the already mentioned Piraeus Harbor in Greece. Additionally, they also began going after European technology and brands. This was in part eased by the lack of geopolitical struggle between the European Union and China at the time (in contrast to United States-China relations), and in part encouraged directly by the Chinese Government, which sought to invest the country's capital outside its borders in its new economic policy. ${ }^{43}$ With regards to the coronavirus crisis, China has once more opted to intensify investment efforts in Europe, this time presenting itself as a rational business partner ready to assist Europe in its economic recovery from the crisis. However, in contrast to the 2008 crisis, the European Union seemed to have learned some lessons with regards to protecting its strategic assets, as evidenced by the European Union regulation that is the subject of this study. ${ }^{44}$

Another aspect is whether the investor has been involved earlier in activities affecting security of public order in a member state, or if there is a serious risk that the foreign investor engages in illegal or criminal activities. ${ }^{45}$ Neither the first nor the second group of factors is a closed list.

${ }^{41}$ Ivana Karásková, 'How China Influences Media in Central and Eastern Europe' The Diplomat (19 November 2019) <https://thediplomat.com/2019/11/how-china-influences-media-in-central-and-eastern-europe> accessed 5 August 2020.

${ }^{42}$ Government Decree 289/2020 (VI. 17.) defining the measures required for the economic protection of companies having their seats in Hungary.

${ }^{43}$ Philippe Le Corre, Alain Sepulchre 'Chinese investors can't get enough of Europe' (Brookings, 10 May 2016) $<$ <ttps://www.brookings.edu/opinions/chinese-investors-cant-get-enough-of-europe> accessed 10 August 2020.

${ }^{44}$ Liisi Karindi, 'How China is buying influence in Europe' Chinaobserver (7 July 2020) <https://chinaobservers. eu/how-china-is-buying-influence-in-europe> accessed 10 August 2020.

${ }^{45}$ Regulation, Art. 4 (2). 


\section{Cooperation mechanisms}

The most important part of the Regulation deals with cooperation mechanisms. Three cases are regulated: firstly, when there is a foreign direct investment into a member state and it is undergoing screening; secondly, when there is a foreign direct investment into a member state and it is not undergoing screening; and the thirdly, when there is a foreign direct investment into a member state which is likely to affect projects or programs in the Union's interest.

Regarding the first mechanism, Article 6(1) of the Regulation requires member states to notify the Commission and other member states of any foreign direct investment in their territory that is undergoing screening. Such notification should contain information provided by Article 9(2) of the Regulation: (a) the ownership structure of the foreign investor and of the undertaking in which the foreign direct investment is planned or has been completed, including information on the ultimate investor and participation in the capital; (b) the approximate value of the foreign direct investment; (c) the products, services and business operations of the foreign investor and of the undertaking in which the foreign direct investment is planned or has been completed; (d) the member states in which the foreign investor and the undertaking in which the foreign direct investment is planned or has been completed conduct relevant business operations; (e) the funding of the investment and its source, on the basis of the best information available to the member state; (f) the date when the foreign direct investment is planned to be completed or has been completed. The notification should also touch on the issue of whether the investment is likely to fall within the scope of the merger regulation. Based on the notification, other member states may issue comments, and the Commission may issue opinions on the investment in question addressed to the member state undertaking the screening. ${ }^{46}$ The member state concerned may also request the Commission to issue an opinion or other member states to provide comments, however, in practice this is unlikely to happen. ${ }^{47}$ The Regulation sets deadlines for the Commission and other member states: they should notify the member state undertaking the screening if they want to provide opinions or comments within 15 days following the receipt of the information on screening. They can also ask for additional information. However, they should send their opinion or comments within 35 days following the receipt of the information on screening. ${ }^{48}$ The Regulation states that the member state undertaking screening 'should give due consideration' to the opinion and comments, but in any case, it is entitled to make the final decision on the investment. ${ }^{49}$

The second mechanism concerns foreign direct investments into member states which are not screened. According to Article 7 (1) of the Regulation where a member

\footnotetext{
${ }^{46}$ Regulation, Art. 6 (1) and (3).

${ }^{47}$ Regulation, Art. 6 (4).

${ }^{48}$ Regulation, Art. 6 (6) (7).

49 Regulation, Art. 6 (9). There is even a provision (Art. 6 (8)) which states that in the exceptional case where the member state undertaking the screening considers that its security or public order requires immediate action it can decide on the investment before the expiry of the deadline, however it should notify the Commission and other member states about it.
} 
state considers that a foreign direct investment planned or completed in another member state which is not undergoing screening in that member state is likely to affect its security or public order, or has relevant information in relation to that foreign direct investment, it may provide comments to that other member state, at the same time sending those comments to the Commission. The Commission is also authorized to issue opinions regarding a foreign direct investment if it considers that it is likely to affect security or public order in more than one member state or has relevant information in relation to that foreign direct investment. If at least one third of member states consider that a foreign direct investment is likely to affect their security or public order, the Commission is obliged to issue such an opinion. ${ }^{50}$ Regarding the opinion of the Commission or comments of other member states, there is the same language used as for the first mechanism, that is to say, 'due consideration' should be given to it by the member state where the foreign investment is planned or has been completed. ${ }^{51}$

The third case is where the Commission considers that a foreign direct investment is likely to affect projects or programs of Union interest on grounds of security or public order. In such a case, the Commission may issue an opinion addressed to the member state where the foreign direct investment is planned or has been completed. The member state concerned should take into account the Commission's opinion. If it does not follow it, it should give an explanation to the Commission. ${ }^{52}$

It can be said that for successful practical application of the Regulation, Article 11 is a key provision. It provides that communication between the member states and the member states and the Commission should be done through so-called contact points established by the parties and placed within their respective administration. ${ }^{53}$ This assures direct cooperation and communication. However, it is questionable whether member states will be honestly willing to provide data and to cooperate in a sensitive area like national security.

Transparency and publicity of screening processes is also ensured by the Regulation. There is a requirement of annual reporting by the member states to the Commission. This also applies to member states which have no screening mechanisms. Based on this information, the Commission reports to the European Parliament and the Council. This report is made public. ${ }^{54}$

\section{Group of experts}

The Regulation deals also briefly with the so-called group of experts which was set up by a Commission Decision in $2017 .{ }^{55}$ The group is composed of representa-

\footnotetext{
${ }^{50}$ Regulation, Art. 7 (2).

${ }^{51}$ Regulation, Art. 7 (7).

${ }^{52}$ Regulation, Art. 8 (1) and (2) (c).

${ }^{53}$ Regulation, Art. 11

54 Regulation, Art. 5.

${ }^{55}$ Commission Decision of 29.11.2017 C(2017) 7866 <https://ec.europa.eu/transparency/regexpert/index. cfm?do=groupDetail.groupDetailDoc\&id=36097\&no=1> accessed 4 August 2020.
} 
tives of member states' competent authorities. The group's task is to provide the Commission with advice and expertise on matters relating to foreign direct investments into the European Union. This includes, among others, identifying assets that have strategic implications from a security, public order and/or control of critical assets and technologies point of view at national level, cross-border level; exchanging information and analysis on foreign direct investments, including motives for investment, geographic origin and sources of financing (public or private); discussing issues of common concern, share best practices and so on. The group shall act at the request of the Directorate-General for Trade.

\section{Conclusions}

Coordination provided by the Regulation is the first step towards harmonization of screening foreign investments in the European Union. However, there are several problems the Union will have to face if it wants to achieve a well-functioning and efficient system. As already mentioned in the introduction, foreign direct investment is part of common commercial policy, with the Union having exclusive competence in this field. However, if the foreign direct investment affects national security, it should be screened by the member state's authorities, and the only tool of the Union to influence it is to provide an opinion. Therefore, it is questionable if the Regulation is setting up an efficient system, as the only tool in the hands of the Commission is political pressure. In addition, lot of member countries still did not realize the importance of screening, and they have no comprehensive regulation on the screening of foreign direct investments. ${ }^{56}$

The biggest obstacle to achieving a well-functioning and well-coordinated screening system in the Union is the large number of member states and their different interests. The largest member states like Germany, France and Italy are those which try to stop the spread of Chinese influence in Europe. They have realized that it is not only about protecting their technology and knowledge, but also about political influence. Some analysts even argue that China's strategy in Europe is 'divide and rule'. And even these countries are not in full accord. For some of them, like Germany, a huge exporter to China, which thus wants to keep good relations with the East Asian country, investment screening is part of their China policy, and they are not willing to give it up. At the same time, as a dominant economy in the European Union, it wants to protect it from Chinese influence.

Some of the smaller member states, like Greece or Portugal, do not really support this kind of mechanism, because they became more reliant on foreign investments following the economic crisis of 2008. In addition, some of them claim that screening might provoke a trade war with economic rivals of the Union.

\footnotetext{
56 There might be other sectoral screening rules in other legislation, like merger, energy sector or pharmaceutical sector which allows member states to protect legitimate interests such as public security, plurality of the media and prudential rules in case of concentrations. Zwartkruis and de Jong (n 23) 8.
} 
It is beyond question that the Regulation has some benefits for the European Union. It might also encourage member states to better utilize their screening mechanisms or to put one into place. In addition, the new system takes into consideration not only the interests of the member state where the investment enters, but also other member states' and the Union's interest. Even in member states where there is no formal screening mechanism there could be a certain level of scrutiny. However, it should be emphasized again that no member state is obliged to conduct a foreign direct investment screening.

Foreign capital is still crucial for every modern economy, especially in hard times. Therefore, the question arises: what will be the result of protectionism in the field of investment law in the European Union? Although some of the regulations in member states are only temporary, if similar pandemics become more frequent, it is possible that the temporary restrictions in national states throughout the European Union will become entrenched, maybe extended towards other European Union members (Europe's lack of unity during the first wave of the pandemic was worrying). A further issue might be that without foreign competition, the monopoly of domestic corporations and corruption in national economies can become enhanced.

The real solution could be a supranational screening system. There are more and more issues that can affect overall European Union security and public order. With Brexit, there is a chance that the integration of member states will get stronger, and the Union will take over more and more competencies from them. This process might be also accelerated by growing competition and protectionism among global powers. 